\title{
フルマウス修復に有効なシリコーン印象法
}

\author{
松波 卓*, 鬼川嘉隆*, 太田裕明*, 岡部俊一*, 児玉信之*, 田嶋紀一郎*, 大石克史**, \\ 大石暢彦**, 植木美輪子**, 稲葉 繁***, IPSGスタディーグループ
}

\section{The silicone impression method for full-mouth reconstraction}

Takashi Matsunami*, Yoshitaka Togawa*, Hiroaki Ohta *, Syunichi Okabe*, Nobuyuki Kodama *, Kiichiro Tajima ${ }^{*}$, Takashi Ohishi ${ }^{* *}$, Nobuhiko Ohishi ${ }^{* *}$, Miwako Ueki**, Shigeru Inaba***, IPSG STUDY GROUP

Silicone impression materials are often used clinically because of their stability in dimensional precision. We performed layering impression (Korrekturabdruck) using putty type and injection type silicone impression materials. By this impression method, initial impression is performed without a spacer. After removal of the initial impression, grooves are made on the impression surface using a groove-cutter, and secondary impression is performed. This technique resulted in clear impressions and preparation of highly compatible prostheses.

シリコーン印象材は寸法精度の安定性から臨床に用いる機会の多い材料である。

この印象材のパテタイプとインジェクションタイプを使い，積層印象（コレクタ・アッ プドルック）を行った。本印象法では，スペーサーを使わずに一次印象を行い，撤去後の 印象面に対しグルーブカッターを用いて溝を付与した後, 二次印象を行う.

その結果，鮮明な印象が採得でき，適合のよい補緅物を作製することができた．

Key words : コレクタ・アップドルック Korrekturabdruck, グルーブカッター groove cutter

\section{緒 言}

日常臨床において補緅物を作製する場合，良好な結果を 得るためには，チェアサイド拈よびラボサイドとも，各ス テップを確実に進めていかなくてはならない。そのなかで も印象採得は，扔ろそかにできない最も重要なステップの 一つである。

したがって術者は，作製する補緅物の種類や目的に応じ て適切な印象材料を選択し，その性質を正しく引き出すよ

\footnotetext{
* 東京都開業

***神奈川県開業

*** 日本歯科大学歯科補経学教室第 3 講座
}

う操作を行わなければならない。シリコーン印象材は, 日 常臨床に抢いて精密印象を行う場合, その寸法精度や操作 性の良さから使用する機会の多い印象材である。

われわれのスタディーグループでは有歯顎の印象採得に おいてシリコーン印象材を利用し，Prof. Lehmanの開発に よる積層印象法（コレクタ・アップドルック）により良好 な結果を得ているので報告する。

\section{方 法}

有歯顎の印象に扔いて, リムロックトレーを使用し, パ テタイプのシリコーン印象材による一次印象, インジェク ションタイプのシリコーン印象材による二次印象を行う。 


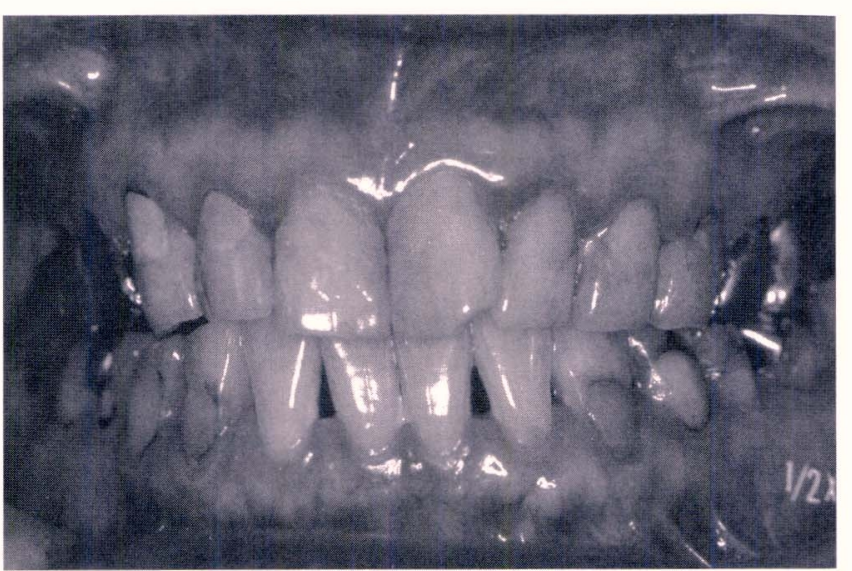

図 1 術前

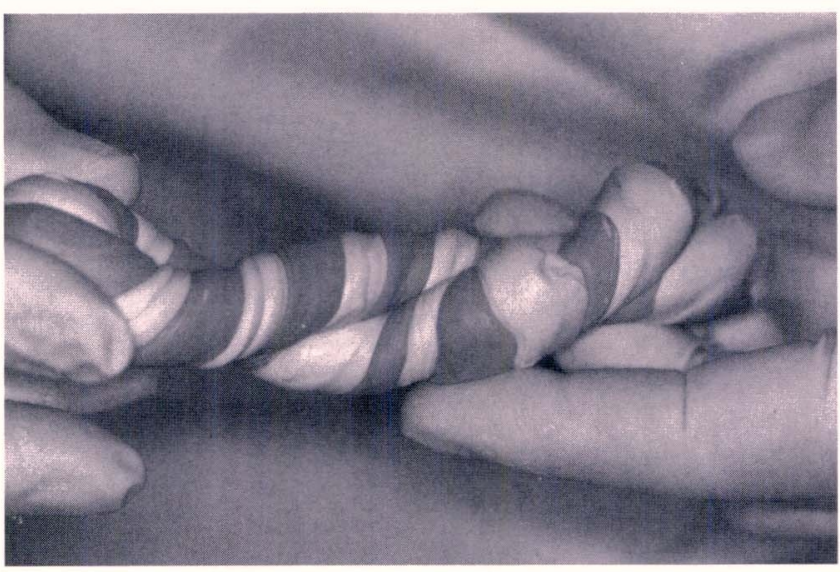

図3棒状にしたベースとキャタリストのパテタイプの印象材を， 捻り合わせたあと引き伸ばし 2つに折る動作を何回も繰り返 すことで，むらなく錬和できる

一次印象に GC 社エクザミックスファインのパテタイ プ, 二次印象に GC社エクザミックスファインのインジェ クションタイプを使用した.

患者は, 53歳の女性で, 顎関節症と審美的な不満を主訴 に来院した，上下顎それぞれにフルマウスの再構成ブリッ ジを行ったので本症例を通じて印象方法を提示する。

(1) 図 1 に術前, 図2に形成が終わり印象前の口腔内 を示す。

（2）リムロックトレーをロ腔内で試適する.

（3）強いアンダーカットや大きい歯間空隙などを確実に リリーフする。この印象法では，スペーサーで歯列を 覆わずに一次印象を行う。そのため, ブリッジのポン ティックの部分やインプラント周辺・顎堤などで強い アンダーカットがある場合, 硬化後のパテタイプ印象 材は弾性がそしいため, 適切なリリーフをしておかな いと口腔内から印象を撤去する際に困難をきたしてし

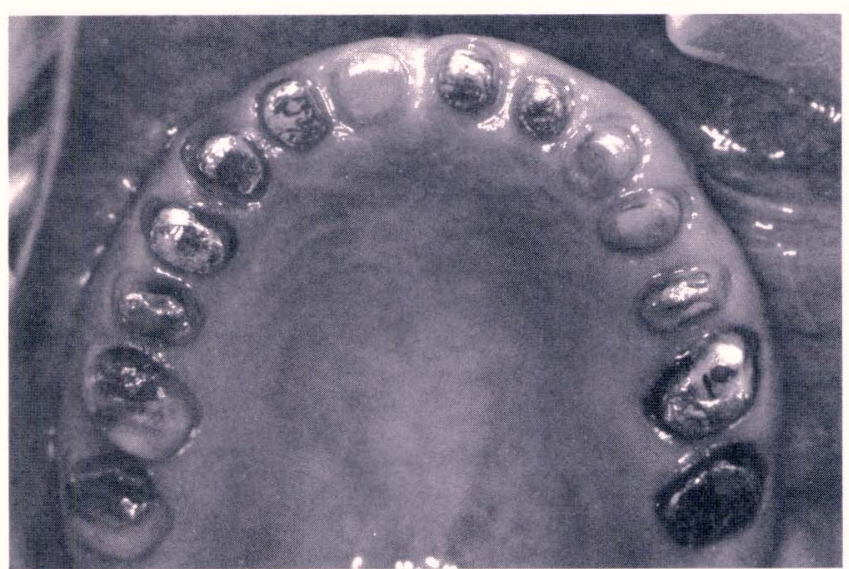

図2 形成終了後

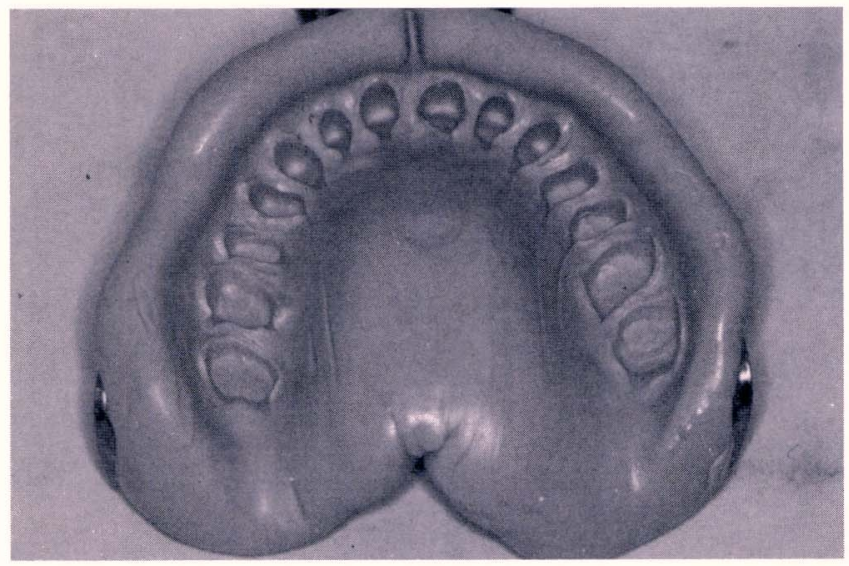

図4 スペーサーを使わずに一次印象を行う

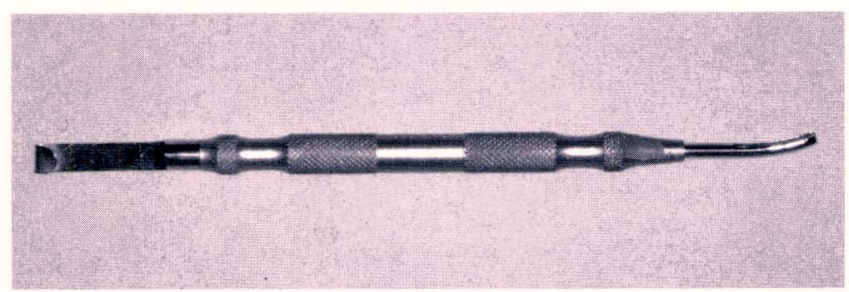

図5 グルーブカッター

まうことがあるので，十分注意する必要がある.

（4）続いて一次印象の操作に入る. パテタイプを錬和し トレーに盛り付ける。キャタリストとベースをそれぞ れ棒状にし，2本を合わせるように伸ばしては折り， 伸ばしては折りという動作を繰り返して錬和していく と，むらなく仕上げることができる（図３）。

（5）トレーを口腔内に入れて硬化まで保持し，その後， 撤去する (図 4).

(6) 続いて二次印象の前準備として一次印象内面に溝を 彫っていく。まず, 歯肉㚘移行部を $5 \mathrm{~mm}$ 程度均等にグ ルーブカッター（図5）を用いてカットする（図6）. 


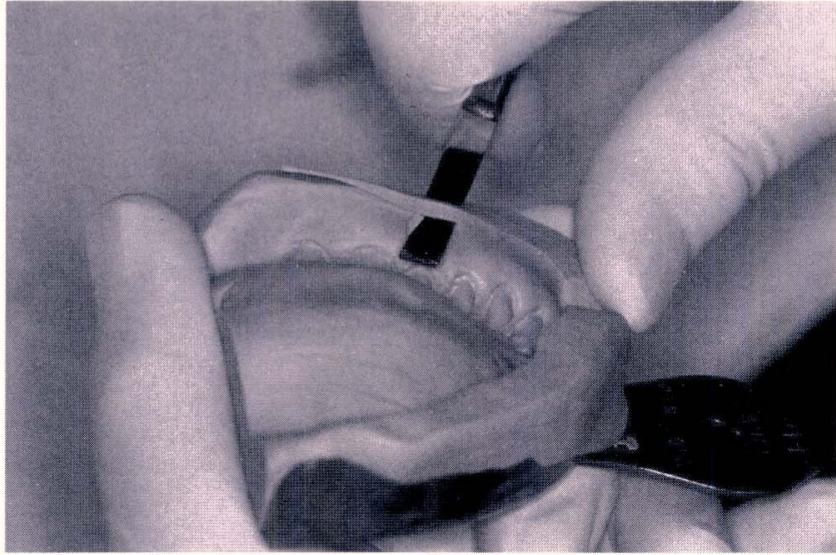

図6 歯肉煩移行部をカットする

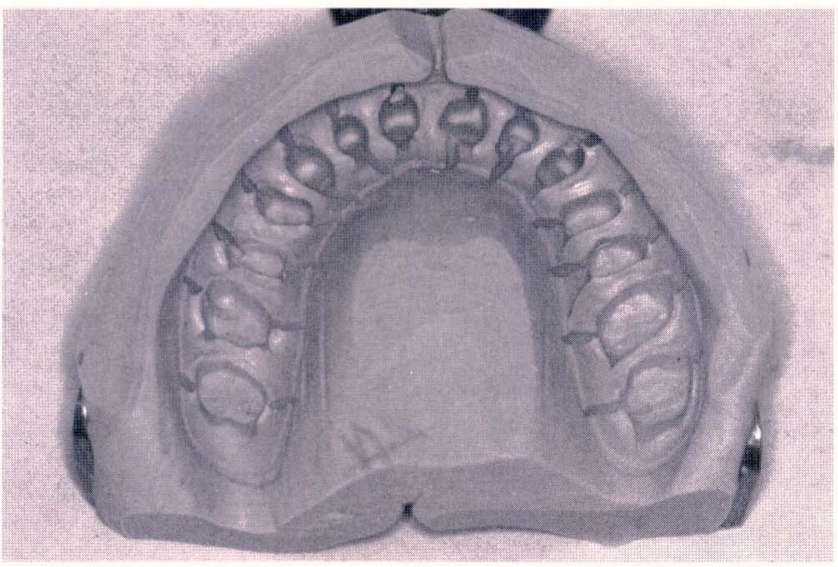

図８横溝より一歯ずつ“縱溝”を彫る

（7）歯頸部の約 $3 \mathrm{~mm}$ 外側に，幅 $2 \mathrm{~mm}$, 媣さ $1.5 \mathrm{~mm}$ 程度 の溝を歯列のまわりを囲むように彫る（図7).

（8）そこから各歯の歯頸部中央に向かい，㚘側と舌側そ れぞれから，先ほど彫った溝と各歯をつなぐよう縦溝 を彫っていく(図8).

（9）槽間中隔部の印象材を取り去る。咬合面の部分は裂 溝がなくなる程度に一層削除する（図９）.

これで一次印象に対する操作は完了する.

(10)これより二次印象を行う。これにはインジェクショ ンタイプの印象材を使用する。印象用のガンを使い， 歯列のスペース全体が埋まる程度の量の印象材を注入 し，口腔内に戻す。歯列に対しトレーが撤去前の位置 に正しく戻っているか確認した後, $2 \sim 3$ 度強く圧接す ると先に付与した溝により歯列全体に均一な圧力が加 わり印象材が行き渡るので，その後硬化するまで保持 する (図 10)。この際，トレーを入れる前に，各々の 支台歯の周囲にシリンジにて印象材を注入する必要が なく，横溝および縦溝を通って印象材が流れ，歯肉部

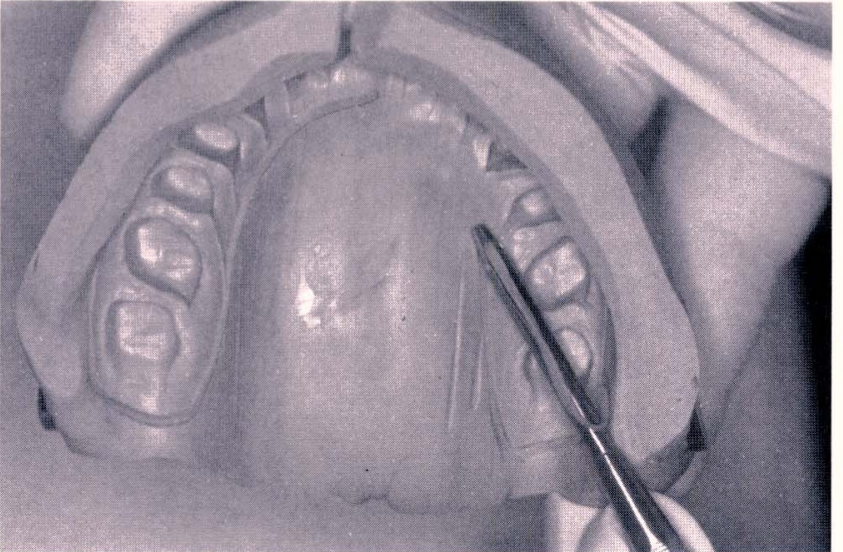

図 7 歯頸部より $3 \mathrm{~mm}$ 程度離して“横溝”を彫る

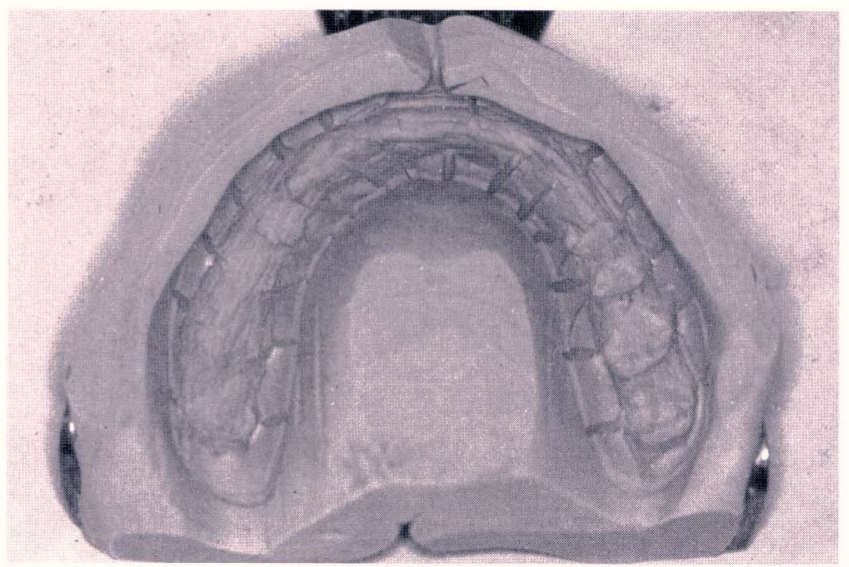

図 9 槽間中隔と咬合面部を一層削除

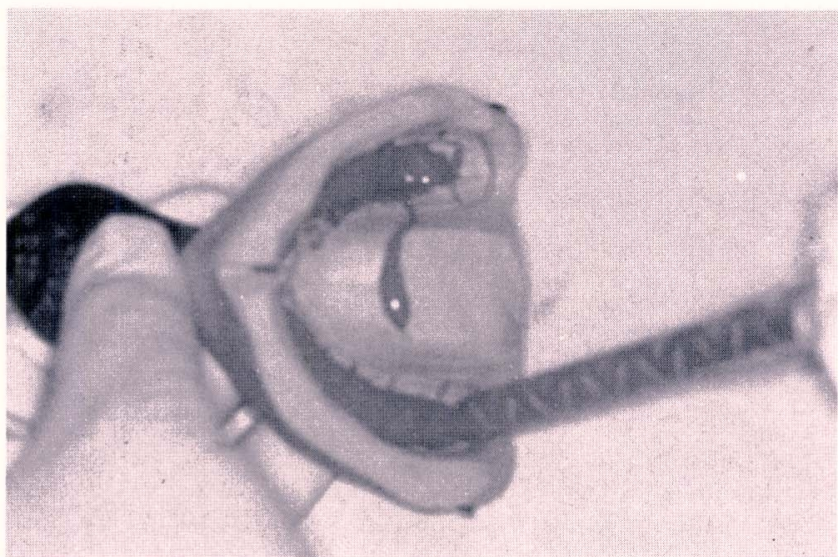

図 10 インジェクションタイプのシリコーン印象材を歯列にそつ て注入する

の封鎖により印象材は歯周ポケットに圧入されるた め，正確な印象が得られることは本印象法の大きな特 徵の一つといえる。

（11）硬化後，撤去する。図 11，12に印象面を示す.

(12）下顎も同様に行う（図 13）. 


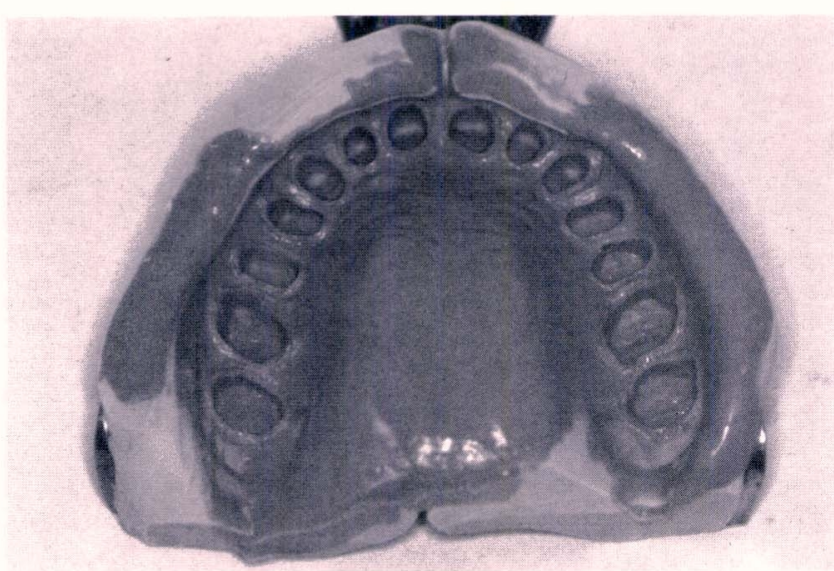

図 11 二次印象が完了

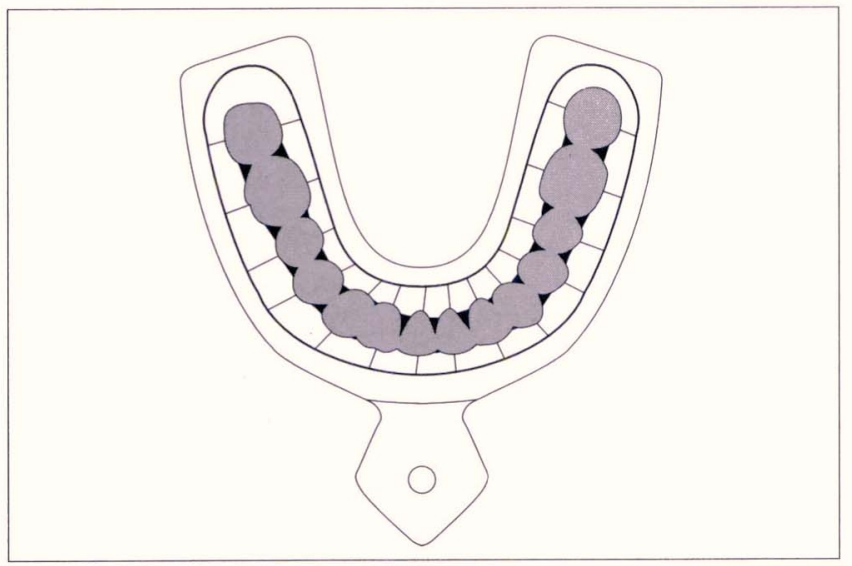

図 13 一次印象内面に付与する溝と削除する部位を示す

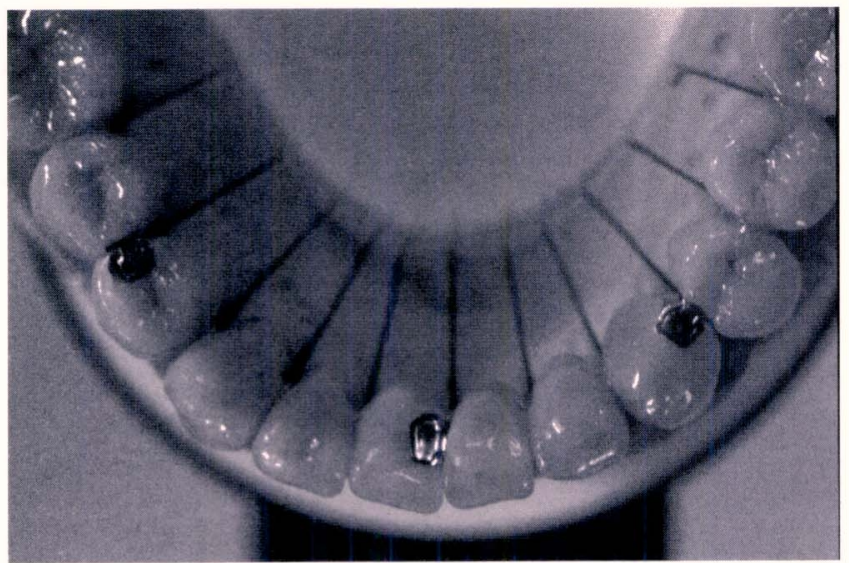

図 15 両側小臼歯部および下顎正中部にキーアンドキーウェイを 設けた（川崎従道氏提供）

(13）印象後, プロビジョナル・レストレーションを松風 社テンポラリーセメントのハードタイプに抗生物質の 軟膏を少量混ぜて仮着した。

（14）この印象を用いて石膏模型を作製し, 補経物を完成 させ，口腔内にセットした（図 14～16）.

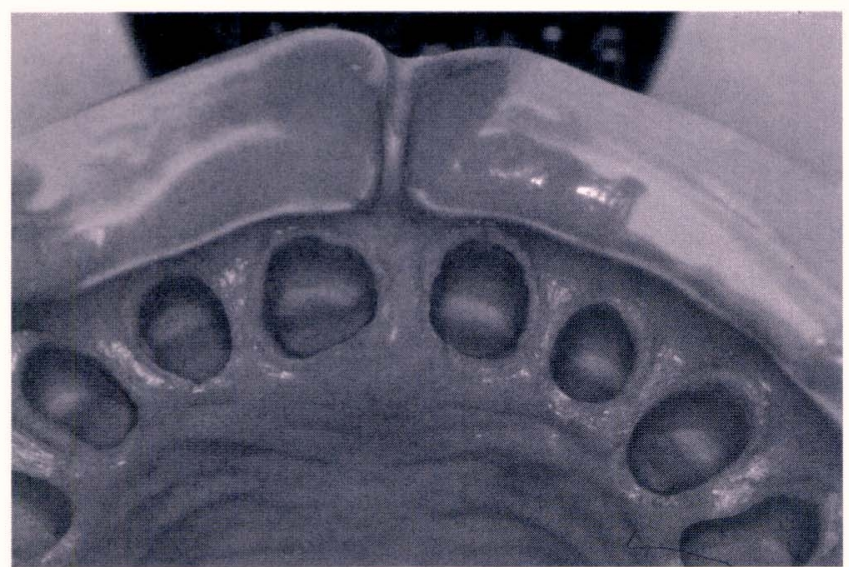

図 12 前歯部

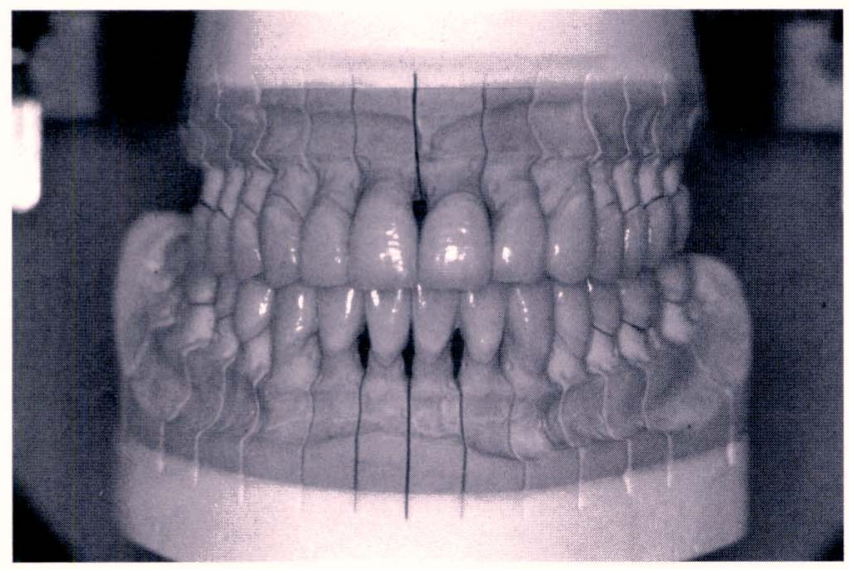

図 14 完成した補緅物

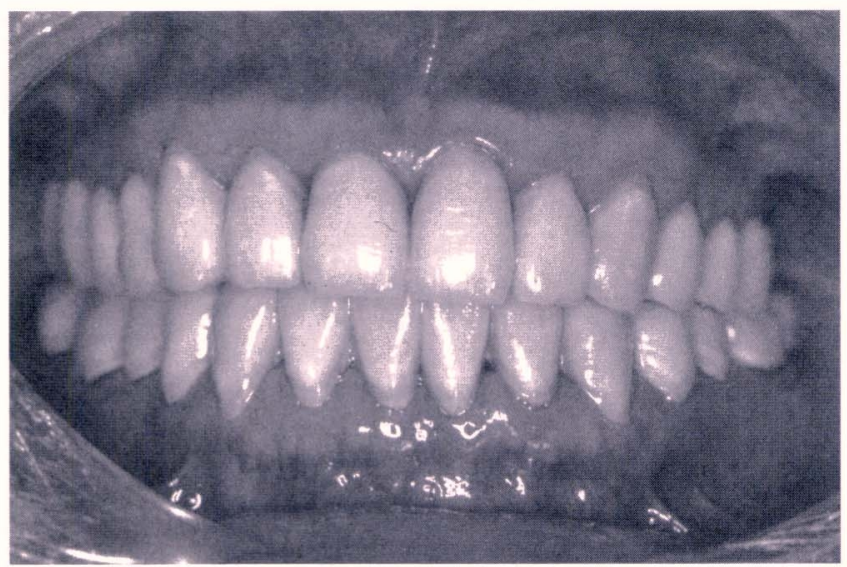

図 16 術後正面観

\section{結 果}

本症例では上下顎に対しフルマウスの補綴物を作製した が, 各支台歯のマージン部分の適合は良好で, 補綴物全体 での適合も全体的な歪みもなく良好であった。 
下顎は両側犬歯および小臼歯部，さらに正中部にもキー アンドキーウェイを設定したが，これは下顎骨が周囲の筋 の緊張により，閉口時よりも開口時に狭くたわみ，補緅物 にストレスがかかることを考慮したためである。

\section{考 察}

印象採得においてマージン部分に気泡を入れないよう配 慮することは絶対条件であるが，そのために通常はシリン ジを用いたり個歯トレーを使用したりすることとなる。

しかし，支台歯が両側にわたり多数ある場合，狭い口腔 内でシリンジを用いて一歯一歯のマージン部に印象材を注 入する作業は, 煩雑な操作である。確実に行おうとすれば するほど時間がかかり，二次印象を口腔内に戻すときには， はじめに盛った印象材のフローが悪くなってしまっている ことも多い. また, 盛り終わった印象材が類粘膜や舌およ び唾液により圧迫されたり流されることを防ぐには，かな り神経を使う必要がある。

一方, 個歯トレーを使用する場合は, 口腔内での操作は やさしくなるが, 個歯トレーのための印象が必要となり, 治療回数と技工のステップが一つ増えることとなる.

したがって, シリンジ・個歯トレーを使わない本印象法 は, 術者と患者のストレスを減らす有効な方法と考える.

この方法では, パスカルの原理, すなわち密閉容器中の 流体はある一点に受けた圧力をそのままの大きさで, すべ ての部分に伝達するという原理により, 簡単確実にマージ ン部に気泡の混入のない印象面を確保することができる.

つまり，一次印象内面に注入したフローのよいインジェ クションタイプの二次印象材（液体）に対し, トレーを歯 列に押し付けることで圧がかかり, 歯頸部方向へと印象材 を流し込むことができるわけである。

槽間中隔と咬合面のパテを削除することで適切なスペー スが確保され，歯列外周に設けた横溝とそこから歯頸部を 連絡する縦溝により, 圧力が印象面全体に均等に分配され る.また，変形のないリムロックトレーを使うことで， シ リコーン印象材の特性を生かした精度のよい印象を採るこ とが可能であると考える。

溝を付与するには「グルーブカッター」というナイフを 使ったが, 歯列の印象内面にはカーブの強いところもある ので，このような形状のものが便利である.

今回の補綴物の作製においては,「クイック・ソルダー システム」という蝋着時のゆがみをなくす技工操作を行っ た. 模型上と口腔内の適合に臨床上差がなかったことから も，印象が正確であったと判断した.

また，歯肉のコンディションは印象の結果に対して影響
が大きいので，良好な状態にしておくことはいうまでもな い. 仮着材に抗生剂を入れることで, 歯質や辺縁歯肉を細 菌感染から防ぎ, 仮着材の劣化を抑制する働きを与えるこ とができた。

一次印象の鍊和であるが，今回の方法では手のひらで錬 和する場合に比べ, 手指の温度が印象材に伝わりにくいと いうメリットがある。

歯肉圧排は, 本症例では行っていない。 二次印象材に圧 力をかけられるため圧排を行わない場合でも支台歯のマー ジン方向に印象材が流れ达んでいくが, 術者の判断で歯肉 圧排が有効と思われる場合は行っても差し支えない.

\section{まとめ}

本積層印象法により，良好な印象採得を行うことができ た.印象採得には，いろいろな材料と方法がある。単純な 操作で短時間に行え, 成功率が高く, より寸法精度のよい 鮮明な印象採得ができることが臨床においては理想であろ う. 気泡が入ってしまったり, 変形する確率が高かったり, 方法が煩雑すぎて再印象がすぐにできないようでは, 日常 頻繁に行う方法としては不適切である.

本印象法は, 特別な器具や装置もほとんど必要なく, 簡 単確実に, インレー一歯の印象から全顎補綴の印象まで同 じ操作で行うことができる. 特に二次印象時, 印象材をシ リンジで口腔内に注入する必要がないため, 多数歯の印象 を採得する症例では有効であると考える。

なお, 本論文の要旨は第 18 回日本口腔健康医学会学術 大会にて発表した.

\section{参考文献}

1) Lehman, K.M., Burgdorf, H.O. : Untersuchungen zu zweizeitigen Abformverfahren fuer kronen und bruecken (Korrekturabdruck). ZWR, 87 : 430-435, 1978.

2) Lehmann, K.M. : Beitrag zur Verbesserung des Korrekturabdruckeverfahrens, Zahnarztl. Prax., 7 : 303-305, 1979.

3) Lehmann, K.H., Burgdorf, H.O. : Untersuchungen zu zweizeitigen Abformverfahren fuer Kronen und Bruecken(Korrekturabdruck). Zahnaerztl. Welt., $87:$ 430, 1978.

4) 国語大辞典 (新装版). 小学館, 1988.

5）川崎従道：金属ソルダースタンドを用いたクイック・ソ ルダーシステム. Quintessence Dent. Technol., 22 : 30-42, 1997.

別刷請求先：松波 卓 